University of Montana

ScholarWorks at University of Montana

$4-2009$

\title{
Invasive Pathogen Threatens Bird-Pine Mutualism: Implications for Sustaining a High-Elevation Ecosystem
}

\author{
Shawn T. McKinney \\ Carl E. Fiedler \\ University of Montana - Missoula, carl.fiedler@cfc.umt.edu \\ Diana F. Tomback
}

Follow this and additional works at: https://scholarworks.umt.edu/forest_pubs

Part of the Forest Management Commons

Let us know how access to this document benefits you.

\section{Recommended Citation}

McKinney, Shawn T.; Fiedler, Carl E.; and Tomback, Diana F., "Invasive Pathogen Threatens Bird-Pine Mutualism: Implications for Sustaining a High-Elevation Ecosystem" (2009). Forest Management Faculty Publications. 16.

https://scholarworks.umt.edu/forest_pubs/16

This Article is brought to you for free and open access by the Forest Management at ScholarWorks at University of Montana. It has been accepted for inclusion in Forest Management Faculty Publications by an authorized administrator of ScholarWorks at University of Montana. For more information, please contact scholarworks@mso.umt.edu. 


\title{
Invasive pathogen threatens bird-pine mutualism: implications for sustaining a high-elevation ecosystem
}

\author{
Shawn T. McKinney, ${ }^{1,3}$ Carl E. Fiedler, ${ }^{1}$ and Diana F. Tomback ${ }^{2}$ \\ ${ }^{1}$ College of Forestry and Conservation, University of Montana, Missoula, Montana 59812 USA \\ ${ }^{2}$ Department of Biology, University of Colorado Denver, P.O. Box 173364, Denver, Colorado 80217 USA
}

Abstract. Human-caused disruptions to seed-dispersal mutualisms increase the extinction risk for both plant and animal species. Large-seeded plants can be particularly vulnerable due to highly specialized dispersal systems and no compensatory regeneration mechanisms. Whitebark pine (Pinus albicaulis), a keystone subalpine species, obligately depends upon the Clark's Nutcracker (Nucifraga columbiana) for dispersal of its large, wingless seeds. Clark's Nutcracker, a facultative mutualist with whitebark pine, is sensitive to rates of energy gain, and emigrates from subalpine forests during periods of cone shortages. The invasive fungal pathogen Cronartium ribicola, which causes white pine blister rust, reduces whitebark pine cone production by killing cone-bearing branches and trees. Mortality from blister rust reaches $90 \%$ or higher in some whitebark pine forests in the Northern Rocky Mountains, USA, and the rust now occurs nearly rangewide in whitebark pine. Our objectives were to identify the minimum level of cone production necessary to elicit seed dispersal by nutcrackers and to determine how cone production is influenced by forest structure and health. We quantified forest conditions and ecological interactions between nutcrackers and whitebark pine in three Rocky Mountain ecosystems that differ in levels of rust infection and mortality. Both the frequency of nutcracker occurrence and probability of seed dispersal were strongly related to annual whitebark pine cone production, which had a positive linear association with live whitebark pine basal area, and negative linear association with whitebark pine tree mortality and rust infection. From our data, we estimated that a threshold level of $\sim 1000$ cones/ha is needed for a high likelihood of seed dispersal by nutcrackers (probability $\geq 0.7$ ), and that this level of cone production can be met by forests with live whitebark pine basal area $>5.0 \mathrm{~m}^{2} /$ ha. The risk of mutualism disruption is greatest in northernmost Montana (USA), where three-year mean cone production and live basal area fell below predicted threshold levels. There, nutcracker occurrence, seed dispersal, and whitebark pine regeneration were the lowest of the three ecosystems. Managers can use these threshold values to differentiate between restoration sites requiring planting of rust-resistant seedlings and sites where nutcracker seed dispersal can be expected.

Key words: Clark's Nutcracker; cone-production threshold; Cronartium ribicola; forest decline mutualism disruption; Northern Rocky Mountains USA; Nucifraga columbiana; Pinus albicaulis; restoration; seed dispersal; white pine blister rust; whitebark pine.

\section{INTRODUCTION}

Plant-animal mutualisms often involve ecological services performed by animal species, e.g., pollination and seed dispersal, in exchange for high-energy food resources, e.g., nectar and seeds. Recent perturbations to such interactions from anthropogenic disturbance raise significant conservation concern (Christian 2001). In theory, the risk of mutualism disruption increases with increasing specialization between plants and the animal species performing the critical service (Bond 1994).

The local extirpation of animal species performing seed-dispersal services has immediate consequences for

Manuscript received 23 January 2008; revised 1 July 2008; accepted 15 July 2008. Corresponding Editor: S. K. Collinge.

3 Present address: Division of Biological Sciences, University of Montana, Missoula, Montana 59812 USA.

E-mail: shawn.mckinney@mso.umt.edu large-seeded plants (McConkey and Drake 2002, Meehan et al. 2002, Travest and Riera 2005). Without seeddispersal vectors, population recruitment is absent or greatly reduced, and the plant mutualist is at risk of local extirpation (Cordeiro and Howe 2001, 2003, Loiselle and Blake 2002). Furthermore, current declines in several plant mutualists caused by exotic pests and pathogens (e.g., Paillet 2002, Rizzo and Garbelotto 2003), and outbreaks of endemic pests and pathogens exacerbated by recent climate warming trends (e.g., Logan and Powell 2001), pose potentially serious threats to animal mutualists. The population responses of animal mutualists to plant declines, as well as the feedback effects on the plants, are currently poorly understood.

The regulation and persistence of animal populations in a given locale are largely determined by food availability and rates of energy assimilation (Lack 
1954). When food is locally scarce, animal species respond by changing their foraging behavior (e.g., seasonal migration). Many granivorous birds in particular respond to fluctuations in conifer cone crops, whereby crop failure is followed by mass emigration of bird populations (Bock and Lepthien 1976). Fluctuation in cone production may be a selective response by trees to reduce predation and increase reproduction (Janzen 1971); but since poor crops are ephemeral, animal populations ultimately return. Contemporary cone production in some forest ecosystems may be more variable over space and time compared to historical conditions because of a myriad of recent health-related influences (e.g., atmospheric warming, air pollution, insect population upsurges, and invasive species). Increased spatial and temporal heterogeneity in cone production would likely impact seed-dispersal mutualisms. For example, if cone-crop declines are met with population declines in the seed disperser, the mutualism would be maintained in a state of dynamic equilibrium, but with fewer seeds dispersed. Furthermore, if a bird species has evolved an emigration response to food scarcity, a prolonged decline in food production may entirely sever the mutualism. In either case, the potential implications would be drastic for both the animal and plant species involved.

The Clark's Nutcracker (Nucifraga columbiana [Wilson], family Corvidae) and whitebark pine (Pinus albicaulis [Engelmann], family Pinaceae, subgenus Strobus) are coevolved mutualists (Tomback 1982, Tomback and Linhart 1990), whereby the pine is obligately dependent upon the bird for dispersal of its large, wingless seeds. In late summer and early fall, nutcrackers extract ripe whitebark pine seeds from cones, transport seeds in a specialized sublingual pouch, and cache them in the ground at an average depth of $2.5 \mathrm{~cm}$ (Tomback 1982). Nutcracker seed dispersal is the primary vector for whitebark pine seedling establishment (Hutchins and Lanner 1982, Tomback 1982). Whereas whitebark pine depends nearly exclusively on nutcrackers, nutcrackers harvest and cache seeds of other large-seeded pines (e.g., Tomback 1978, 1998).

Clark's Nutcracker life history is closely tied to Pinus seed production (Tomback 1978, 1998). Nutcrackers forage on fresh pine seeds throughout the summer and fall, and use their seed caches for winter and spring food, as well as for feeding nestlings (Mewaldt 1956, Vander Wall 1988). The seed caches of a single nutcracker yield an estimated 1.8-5 times the energy required to survive the winter (Vander Wall and Balda 1977, Tomback 1982, Vander Wall 1988). Based on metabolic requirements, Tomback (1982) estimated that a local population of nutcrackers consumes $55 \%$ of their stored seeds. Furthermore, nutcrackers are sensitive to rates of energy gain: they increase their foraging efficiency by selecting trees with ripe cones and with higher cone densities, and cones with higher proportions of edible seeds (Vander
Wall and Balda 1977, Tomback 1978, Tomback and Kramer 1980, Vander Wall 1988).

In early summer, nutcrackers forage in subalpine forests and assess the developing cone crop (Vander Wall 1988). This behavior presumably alerts birds to imminent seed shortages (Vander Wall et al. 1981). Depending on the severity of cone crop failure, nutcrackers either emigrate regionally or irrupt synchronously from large geographic areas, e.g., the Sierra Nevada, in search of food (Davis and Williams 1957, 1964, Bock and Lepthien 1976). The surviving nutcrackers apparently return to subalpine forests in the spring following mass migration and again assess the current year's cone crop (Vander Wall et al. 1981). Thus, the size, mortality, and reproductive rates of nutcracker populations are likely closely associated with cone production of their preferred Pinus species.

Cronartium ribicola, an invasive fungal pathogen, causes white pine blister rust in five-needle white pines (genus Pinus, subgenus Strobus). Since its introduction to western North America in 1910 (see McDonald and Hoff [2001] for review), blister rust has spread throughout nearly the entire range of whitebark pine, with mortality exceeding $90 \%$ in some Rocky Mountain forests (Keane et al. 1994, Kendall and Keane 2001, Schwandt 2006). Blister rust reduces cone production by girdling and killing cone-bearing branches and trees (McDonald and Hoff 2001). In western Montana and eastern Idaho, whitebark pine cone production was significantly lower in rust-damaged stands compared to stands with little damage but otherwise similar in forest structure and composition (McKinney and Tomback 2007). Furthermore, lower cone production in rustdamaged stands was associated with significantly higher rates of predispersal seed predation and fewer observations of nutcracker seed dispersal (McKinney and Tomback 2007).

The long-term persistence of whitebark pine in the presence of blister rust will require a dramatic increase in the frequency of rust-resistant alleles, which is estimated to be only $1 \%$ to $5 \%$ within populations first exposed to the rust (Hoff et al. 1994). Losses of whitebark pine to blister rust are further complicated by ongoing outbreaks of mountain pine beetles (Dendroctonus ponderosae), which use whitebark pine as host trees, resulting in additional mortality (Logan and Powell 2001). The overall recovery strategy for whitebark pine includes both restoration planting of nursery-grown, rust-resistant seedlings and facilitated natural regeneration (focused silvicultural cutting and prescribed burning to provide hospitable sites for nutcracker caching) to spread rust-resistant genes (Keane and Arno 2001, Schoettle 2004, Mahalovich et al. 2006, Schwandt 2006). Because restoration planting is costly, spatially restricted, and uncertain in outcome, the naturalregeneration approach should be implemented wherever feasible (i.e., where the probability of nutcracker seed dispersal is high). 
Given the nutcracker's tendency to emigrate when cone crops are small, and because of increasing losses of cone production capacity within forest stands, the nutcracker-whitebark pine mutualism risks local and even regional disruption. Therefore, we pose the question: Is there a threshold of whitebark pine cone production necessary to elicit seed dispersal by nutcrackers? To address this question, we quantified the relationship between cone production and whitebark pine stand structure and health condition, and modeled the probability of nutcracker seed dispersal as a function of cone production.

\section{Methods}

\section{Sampling design}

We established multiple research sites within three distinct ecosystems in the Central and Northern Rocky Mountains, USA (Fig. 1): (1) the Northern Divide Ecosystem in northwestern Montana included 10 study sites located in Glacier National Park and the adjacent Flathead National Forest $\left(48^{\circ} 48^{\prime} \mathrm{N}\right.$ to $48^{\circ} 18^{\prime} \mathrm{N}, 113^{\circ} 18^{\prime}$ W to $114^{\circ} 24^{\prime} \mathrm{W}$; 1928-2209 $\mathrm{m}$ above sea level [asl]), (2) the Bitterroot Mountain Ecosystem in west-central Montana and east-central Idaho comprised six sites in the Bitterroot and Salmon National Forests $\left(46^{\circ} 30^{\prime} \mathrm{N}\right.$ to $45^{\circ} 30^{\prime} \mathrm{N}, 113^{\circ} 54^{\prime} \mathrm{W}$ to $114^{\circ} 24^{\prime} \mathrm{W}$; 2364-2648 $\mathrm{m}$ asl), and (3) the Greater Yellowstone Ecosystem in southwestern Montana and northwestern Wyoming was represented by eight sites located in Yellowstone National Park and the Gallatin and Shoshone National Forests $\left(45^{\circ} 6^{\prime} \mathrm{N}\right.$ to $44^{\circ} 48^{\prime} \mathrm{N}, 109^{\circ} 30^{\prime} \mathrm{W}$ to $110^{\circ} 36^{\prime} \mathrm{W}$; 2529-2970 m asl). The Northern Divide Ecosystem is located $\sim 300 \mathrm{~km}$ north of the Bitterroot Mountain Ecosystem, whereas the Greater Yellowstone Ecosystem is situated $\sim 300 \mathrm{~km}$ southeast (Fig. 1).

We chose the three study ecosystems because they represent distinct points along a gradient of whitebark pine forest conditions (i.e., tree mortality and blister rust infection). Individual research sites were located within $16 \mathrm{~km}$ from a trailhead and were selected based on the presence of cone-bearing whitebark pine, while multiple research sites within ecosystems were selected to capture variation in tree-species composition and structure, and in the altitudinal range of whitebark pine. Mean intersite distance within an ecosystem was $7.1 \pm 2.4 \mathrm{~km}$ (mean $\pm \mathrm{SE}$ ). We established sites by delineating rectangular boundaries that were $100 \mathrm{~m}$ wide by $\geq 200$ $\mathrm{m}$ long within contiguous forest stands (site area: minimum $=2$ ha, maximum $=7$ ha, mean $=2.6$ ha) . The actual size of a site was determined by the density of cone-bearing whitebark pine, so that forests with low densities of cone-bearing trees (e.g., 1 tree/ha) required larger sampling areas. Sites were subdivided into 1-ha squares $(100 \times 100 \mathrm{~m})$ for focused nutcracker and forestcommunity sampling (Fig. 2). Thus, the research site was the unit of investigation, and was comprised of multiple 1-ha squares.

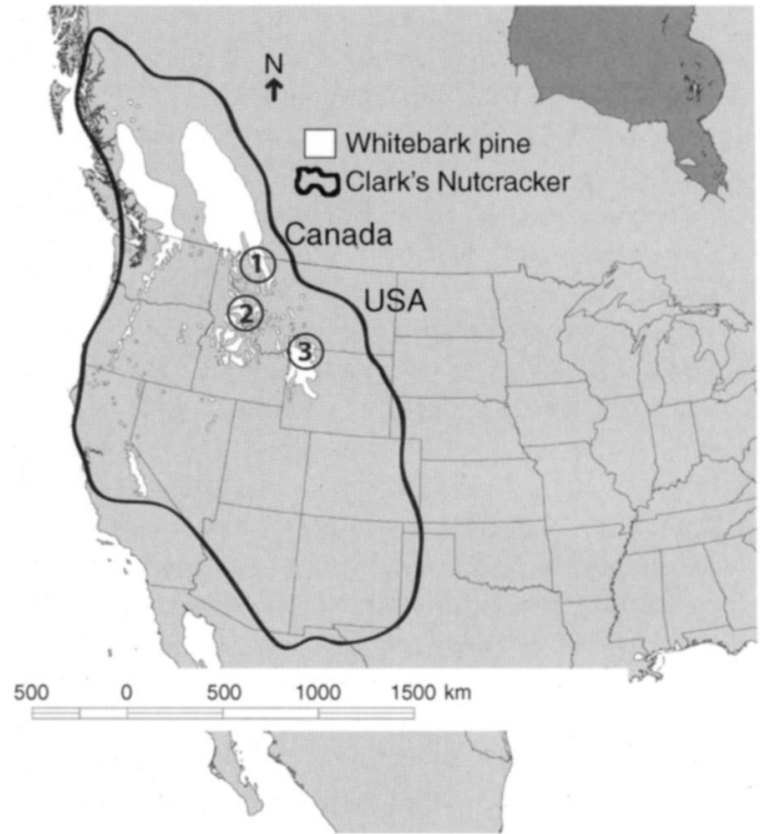

FIG. 1. Geographic distribution of whitebark pine (Pinus albicaulis) and Clark's Nutcracker (Nucifraga columbiana), including locations of the three study ecosystems: (1) Northern Divide, (2) Bitterroot Mountains, and (3) Greater Yellowstone. Whitebark pine range was derived from Little (1971; see $\langle\mathrm{http}: / /$ esp.cr.usgs.gov/data/atlas/little/ $\rangle$ ), and Clark's Nutcracker range from Tomback (1998)

Field sampling took place each year from June to September, however, not every site was visited every year. Northern Divide sites were sampled in $2004(n=10$ sites), 2005 ( $n=6$ sites), and 2006 ( $n=4$ sites); Bitterroot Mountain sites in 2001 ( $n=4$ sites), 2002 ( $n=4$ sites), and 2006 ( $n=2$ sites); and Greater Yellowstone sites in 2005 ( $n=6$ sites) and 2006 ( $n=6$ sites).

\section{Cone production, forest composition, and forest health}

Random numbers for azimuth degree and distance were generated from a corner of each 1-ha square within a site and followed until an ovulate cone-bearing whitebark pine tree was encountered. Because whitebark pine often grows in clumps, we considered a "conebearing whitebark pine tree" to be any single stem or multiple-stem clump where $\geq 2$ stems were joined below $1.4 \mathrm{~m}$ height (McKinney and Tomback 2007). We measured the diameter $( \pm 0.1 \mathrm{~cm})$ at breast height $(\mathrm{dbh}$, $1.4 \mathrm{~m}$ ) and calculated basal area (BA) from the dbh of each cone-bearing whitebark pine tree. If $\geq 2$ stems were present, we calculated BA for each stem and summed the values to obtain a single BA for a given cone-bearing tree. We attached metal identification tags to cone trees and logged their coordinates with a global positioning system unit (GPS; Garmin International, Olathe, Kansas, USA). The same procedure was followed again, only now beginning at the previously selected cone tree. Selected cone trees were a minimum of $25 \mathrm{~m}$ apart, with 
Cone-bearing whitebark pine tree

IIIII $10 \times 50 \mathrm{~m}$ belt transect

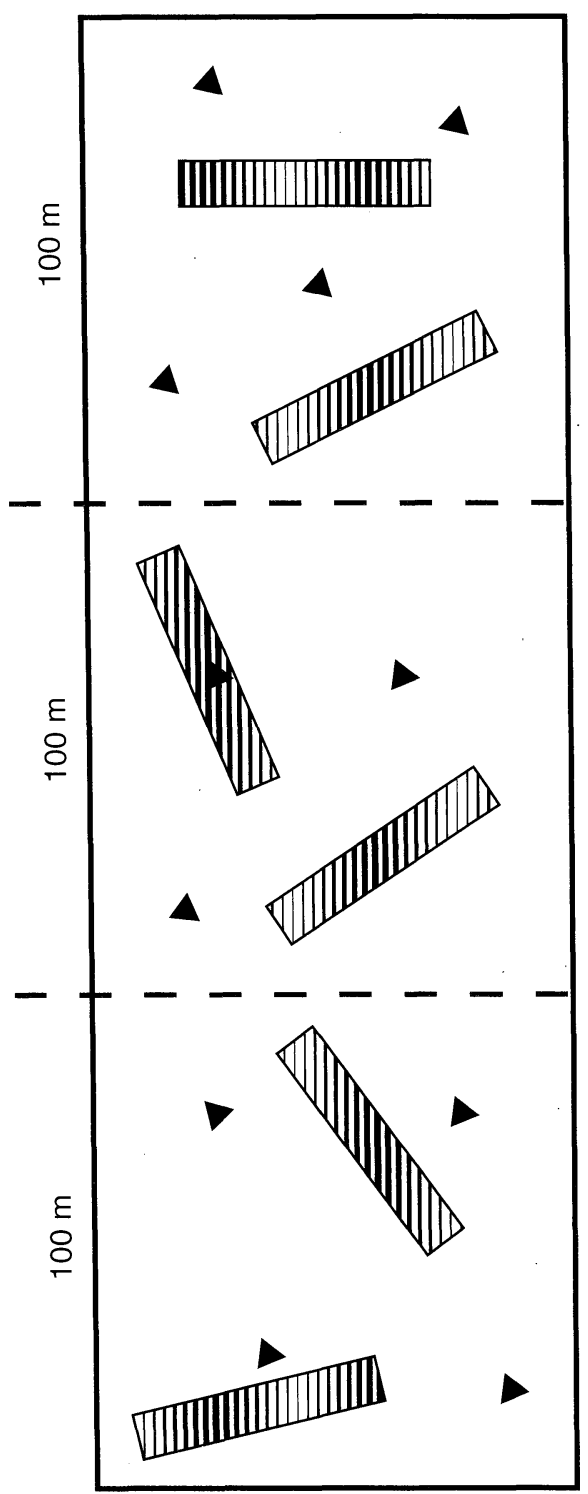

$100 \mathrm{~m}$

FIG. 2. Site-level sampling design employed in this study. Each site $(n=24$ sites) consisted of two to four $100 \times 100 \mathrm{~m} \mathrm{(1}$ ha) squares that provided spatial control over forest structure, composition, and nutcracker sampling. Two $10 \times 50 \mathrm{~m}$ belt transects and 1-4 whitebark pine cone-bearing tees were sampled per 1-ha square in each research site.

one to four sampled trees per hectare. We condúcted cone counts on each selected tree between 29 June and 15 July of each year using tripod-mounted spotting scopes (Leica Camera, Solms, Germany) with $10 \times$ to $60 \times$ zoom eyepieces and handheld counters. Two to three observation points that allowed for unobstructed views of the canopy were used to count cones on each tree. Sampling dates were chosen based on a previous study in the Rocky Mountains that identified the onset of predispersal seed predation by red squirrels (Tamiasciurus hudsonicus) to be mid-July (McKinney and Tomback 2007). This approach helped to control for impacts of squirrel predation because one of our main objectives was to determine how cone production is influenced by forest structure and health.

We established two $10 \times 50 \mathrm{~m}\left(500 \mathrm{~m}^{2}\right)$ belt transects along random azimuths within each 1-ha square at each research site to collect tree- and site-level data (Fig. 2). We recorded species and dbh for all trees $\geq 7 \mathrm{~cm} \mathrm{dbh}$. We calculated BA from the dbh for each tree and summed BA by transect, species, and research site. We inspected all living whitebark pine trees $\geq 7 \mathrm{~cm}$ dbh for the presence of ovulate cones and blister rust infection symptoms. A tree with active or inactive branch or stem cankers, which are swellings caused by the rust's mycelia growing into branch or stem phloem tissue (McDonald and Hoff 2001), was classified as "infected" (Hoff 1992). On each transect, we also measured dbh of standing dead whitebark pine trees and tallied all whitebark pine seedlings $\leq 50 \mathrm{~cm}$ in height.

Site-level whitebark pine cone production estimates were calculated using two independent sampling methods. First, we performed detailed cone counts on a subsample of 1-4 cone-bearing trees per hectare, sampling over multiple hectares within a site, and then calculated the mean number of cones per tree. Second, we obtained an estimate of the number of cone-bearing trees per hectare through belt transect sampling (sampling intensity $=1000 \mathrm{~m}^{2} /$ ha). Whitebark pine cone production estimates were calculated as the product of the mean number of cones per tree and the mean number of cone-bearing trees per hectare for each research site-year ( $n=42$ site-year combinations), and for overall site means ( $n=24$ sites).

\section{Clark's Nutcracker observations}

Research sites were visited at least once in each of three periods during a field season: 29 June to 17 July, 20 July to 16 August, and 19 August to 6 September. Nutcracker observations were conducted between 07:00 and 19:00 hours and followed the protocol established by McKinney and Tomback (2007): one researcher moved throughout a 1-ha square and recorded the number of nutcrackers observed within a 1-h period, avoiding a double count of birds. Nutcracker foraging behavior was classified as either seed predation or seed dispersal. Nutcrackers consume unripe whitebark pine seeds in early-to-mid-summer, acting as seed predators, but become seed dispersers when seed caching begins in late summer and early fall (see Tomback [1998] for overview). We counted a seed-dispersal event when a nutcracker placed whitebark pine seeds in its sublingual pouch, or had a bulging sublingual pouch (Vander Wall and Balda 1977, Tomback 1978), and a seed-predation 
TABLE 1. Values of whitebark pine forest health from three ecosystems in the Rocky Mountains, USA.

\begin{tabular}{lccr}
\hline \hline \multirow{2}{*}{$\begin{array}{c}\text { Ecosystem, and } \\
\text { no. of research sites }\end{array}$} & \multicolumn{3}{c}{ Health parameters } \\
\cline { 2 - 4 } Northern Divide, 10 & $82.2^{\mathrm{al}}(6.7)$ & Tree mortality $(\%)$ & Live basal area $\left(\mathrm{m}^{2} / \mathrm{ha}^{\mathrm{a}}\right)$ \\
Bitterroot Mountains, 6 & $64.9^{\mathrm{ab}}(11.4)$ & $68.4^{\mathrm{a}}(4.1)$ & $1.9^{\mathrm{a}}(0.6)$ \\
Greater Yellowstone, 8 & $49.3^{\mathrm{b}}(7.6)$ & $17.3^{\mathrm{b}}(3.7)$ & $10.5^{\mathrm{b}}(3.6)$ \\
\hline
\end{tabular}

Notes: Data are means, with SE in parentheses. Ecosystems with the same superscript lowercase letter are not statistically different at $\alpha=0.05$ (Scheffe's multiple-comparisons test).

event when a nutcracker was seen consuming whitebark pine seeds (i.e., not filling its sublingual pouch).

\section{Data analyses}

We used S-Plus 7.0 (Insightful Corporation 2005), SPSS 10.0 (SPSS 1999), and Microsoft Excel (Microsoft Corporation 2003) for all computations and analyses. Statistical tests were evaluated at an a priori significance level of $P=0.05$. Analyses of habitat use were conducted at multiple spatial (site and ecosystem) and temporal (individual year and all years) levels, and data were summarized accordingly. We converted nutcracker data to the proportion of total observation hours (all years combined) with $\geq 1$ bird detected for each research site ( $n=24$ sites). We then calculated the mean number of nutcrackers (no. birds/h) occurring within each ecosystem by summing the number of birds across study sites detected in each ecosystem and dividing by the corresponding total number of observation hours. Each research site within a given year (site-year, $n=42$ ) was coded as one (1) if we observed at least one nutcracker seed-dispersal event and zero (0) if not.

We performed simple linear-regression analysis of the overall proportion of observation hours (all years combined) with $\geq 1$ nutcracker on mean whitebark pine cone production across all research sites ( $n=24$ sites) to investigate the influence of food-energy availability on nutcracker occurrence. Cone-production estimates were transformed to $\ln (\text { cones } / \mathrm{ha})^{2}$ to meet assumptions of normality, and residual analysis was performed to confirm assumptions of homoscedasticity of error variance. We used correlation analysis (Pearson's simple correlation coefficient) to quantify the strength of the linear relationships among site-level values of nutcracker occurrence, cone production, live whitebark pine basal area, and mortality to investigate how bird occurrence and food production were related to measurable forest variables affected by blister rust. Cone production was transformed as above and basal area was natural logtransformed to satisfy normality assumptions.

We used a logistic-regression model with binomial error and a logit link to estimate intercept and slope $\left(b_{0}\right.$ and $b_{1}$ ) coefficients for the probability of nutcracker seed dispersal as a function of transformed whitebark pine cone production ( $n=34$ sites). Eight sites were randomly selected and held out from the logistic analysis. Cone production and seed-dispersal outcomes from the eight sites were then used with the estimated coefficients $b_{0}$ and $b_{1}$ to evaluate the predictive ability of the seed-dispersal model. Lastly, we performed a $\chi^{2}$ test to determine whether the proportion of sites with nutcracker seed dispersal differed among ecosystems.

To determine whether and how ecosystems differed in whitebark pine forest health parameters, we performed a multivariate analysis of variance (MANOVA) and used Scheffe's post hoc multiple-comparisons tests of ecosystem values for blister rust infection incidence (percentage, \%), tree mortality (percentage, \%), and live basal area (in $\mathrm{m}^{2} /$ ha). The $F$ statistic for Box's test and Levene's test were evaluated to determine whether equality of covariance matrices and error variances among groups were violated, respectively.

\section{RESUlTS}

The three measures of whitebark pine forest healthblister rust infection (\%), tree mortality (\%), and live basal area $\left(\mathrm{m}^{2} / \mathrm{ha}\right)$-varied among the three ecosystems (Table 1). There was a significant difference in the population mean vectors for the three variables among ecosystems (MANOVA, Wilks' lambda $F_{6,38}=11.43, P$ $<0.001$ ), with univariate analysis-of-variance tests showing significant differences in population mean values for infection $\left(F_{2,21}=4.47, P=0.024\right)$, mortality $\left(F_{2,21}=54.73, P<0.001\right)$, and live basal area $\left(F_{2,21}=\right.$ $10.11, P=0.001)$. Northern Divide sites had significantly greater infection and mortality levels and lower live whitebark pine basal area than Greater Yellowstone sites, and significantly greater mortality and lower live whitebark pine basal area than Bitterroot Mountain sites $(P<0.05$ all pairwise comparisons: Table 1$)$. Research sites in the Bitterroot Mountains were not significantly different than those in the Greater Yellowstone with respect to these variables $(P>0.05$ all pairwise comparisons: Table 1).

The proportion of total observation hours (all years combined) with at least one Clark's Nutcracker sighting increased linearly with increasing values of transformed whitebark pine cone production $\left(\ln [\text { cones } / \text { ha }]^{2}\right)$ across all research sites $\left(R^{2}=0.765\right.$; Fig. 3$)$. This regression model was highly significant (Model $F_{1.22}=71.68, P<$ 0.001 ), indicating that the frequency of nutcracker occurrence at a site was strongly associated with the number of available cones, and thus potential food energy for the bird. Further, the model's estimated intercept and slope coefficients indicate that nutcracker occurrence in a whitebark pine forest becomes negligible 


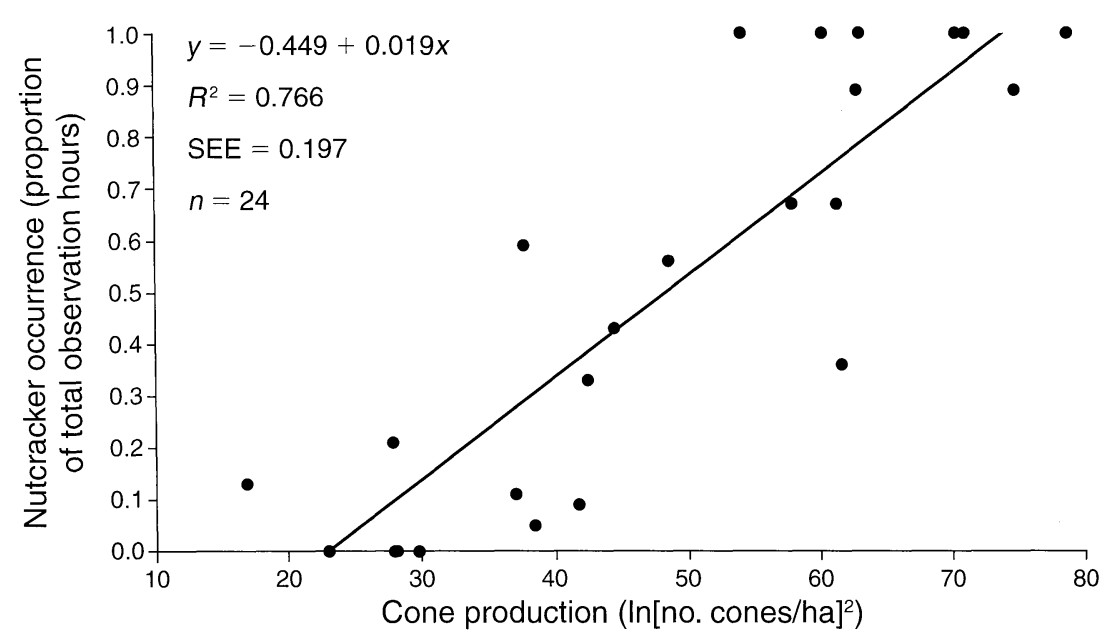

FIG. 3. Simple linear-regression analysis of the proportion of total observation hours (all years combined) with $\geq 1$ Clark's Nutcracker present as a function of mean transformed whitebark pine cone production in Rocky Mountain forest sites. SEE indicates the standard error of the estimate (proportion).

(proportion $\approx 0)$ when cone production averages $<130$ cones/ha (ln [cones/ha $]^{2}<23.64$; Fig. 3$)$.

Both nutcracker occurrence (proportion of observation hours, all years combined per site) and cone production (mean of all years per site) were negatively correlated with whitebark pine tree mortality (\%), and positively correlated with live whitebark pine basal area ( $\ln \mathrm{BA}$, in $\mathrm{m}^{2} / \mathrm{ha}$ ) at the site level (Table 2), suggesting that these measurable site variables can be important indicators of cone production and thus, bird occurrence.

Annual nutcracker occurrence fluctuated with annual whitebark pine cone production within and among ecosystems (Fig. 4). Within ecosystems, when a given year's cone production was greater relative to other years, the frequency of nutcracker occurrence was also greater. This trend was true for each ecosystem-year (i.e., a given ecosystem on a given year; $n=8$ ) except for the Northern Divide in 2006; in that ecosystem-year, cone production was slightly lower than 2005, while nutcracker occurrence was slightly higher (Fig. 4). Among ecosystems, cone production and nutcracker occurrence were lowest each sample year in the Northern Divide and highest in the Greater Yellowstone (Fig. 4). Annual variation in both variables was greatest within the Bitterroot sites, perhaps reflecting the greater heterogeneity in blister rust infection and live whitebark pine basal area among research sites within that ecosystem (Fig. 4, Table 1).

We used seed-dispersal results (i.e., whether or not a seed-dispersal event was recorded) from 34 site-years in a binary logistic-regression model to estimate the probability of seed dispersal as a function of transformed whitebark pine cone production ( $\ln [\text { cones } / \text { ha }]^{2}$; Fig. 5). Using a cutoff probability value of 0.50 , the model correctly classified $92.3 \%(12 / 13)$ and $90.5 \%$ $(19 / 21)$ of the original nondispersed and dispersed siteyears, respectively, with $91.2 \%(31 / 34)$ of all original site-years correctly classified. Thus, the model predicted nondispersed and dispersed sites equally well. We also randomly selected, and held out from the logistic regression, cone production and seed-dispersal data from eight site-years to use with the model's estimated coefficients $\left(b_{0}\right.$ and $\left.b_{1}\right)$ to further assess its predictive ability. Five of the eight $(60 \%)$ site-years were correctly classified (cutoff probability $=0.50$; Appendix). The three misclassified site-years were nondispersed, had intermediate cone production values, and were predicted to have dispersal probabilities $>0.50$, but $<0.70$ (Appendix). This test demonstrated that the model performed better at low and high cone production values. However, when the cutoff probability of seed dispersal was set equal to 0.70 , only $5.3 \%(1 / 19)$ of all nondispersed sites were misclassified and predicted to have seed dispersal (Fig. 5, Appendix A). Based on the logistic-regression model equation, a whitebark pine forest has a predicted seed-dispersal probability $\geq 0.70$ when average cone production $\geq 700$ cones/ha (ln [cones/ ha $]^{2} \geq 42.9$; Fig. 5).

TABLE 2. Pearson's simple correlation coefficients of Clark's Nutcracker occurrence and whitebark pine site characteristics in the Rocky Mountains, USA.

\begin{tabular}{lccc}
\hline \hline & $\begin{array}{c}\text { Cone production } \\
\left(\ln [\text { cones/ha] }]^{2}\right) \dagger\end{array}$ & $\begin{array}{c}\text { Tree } \\
\left(\operatorname{ln~m}^{2} / \mathrm{ha}\right) \dagger\end{array}$ & $\begin{array}{c}\text { mortality } \\
(\%) \dagger\end{array}$ \\
\hline $\begin{array}{c}\text { Nutcracker occurrence } \\
(\text { proportion of time) }\end{array}$ & 0.875 & 0.793 & -0.797 \\
$\begin{array}{c}\text { Cone production } \\
\left(\ln [\text { cones } / \mathrm{ha}]^{2}\right) \dagger\end{array}$ & 0.808 & -0.711 \\
$\begin{array}{c}\text { Basal area } \\
\left(\operatorname{ln~} \mathrm{m}^{2} / \mathrm{ha}\right) \dagger\end{array}$ & & -0.779 \\
\hline
\end{tabular}

Note: Correlations are based on site-level mean values and are all significant at $\alpha=0.01$ ( $n=24$ sites).

$\dagger$ Values are for whitebark pine trees only. 

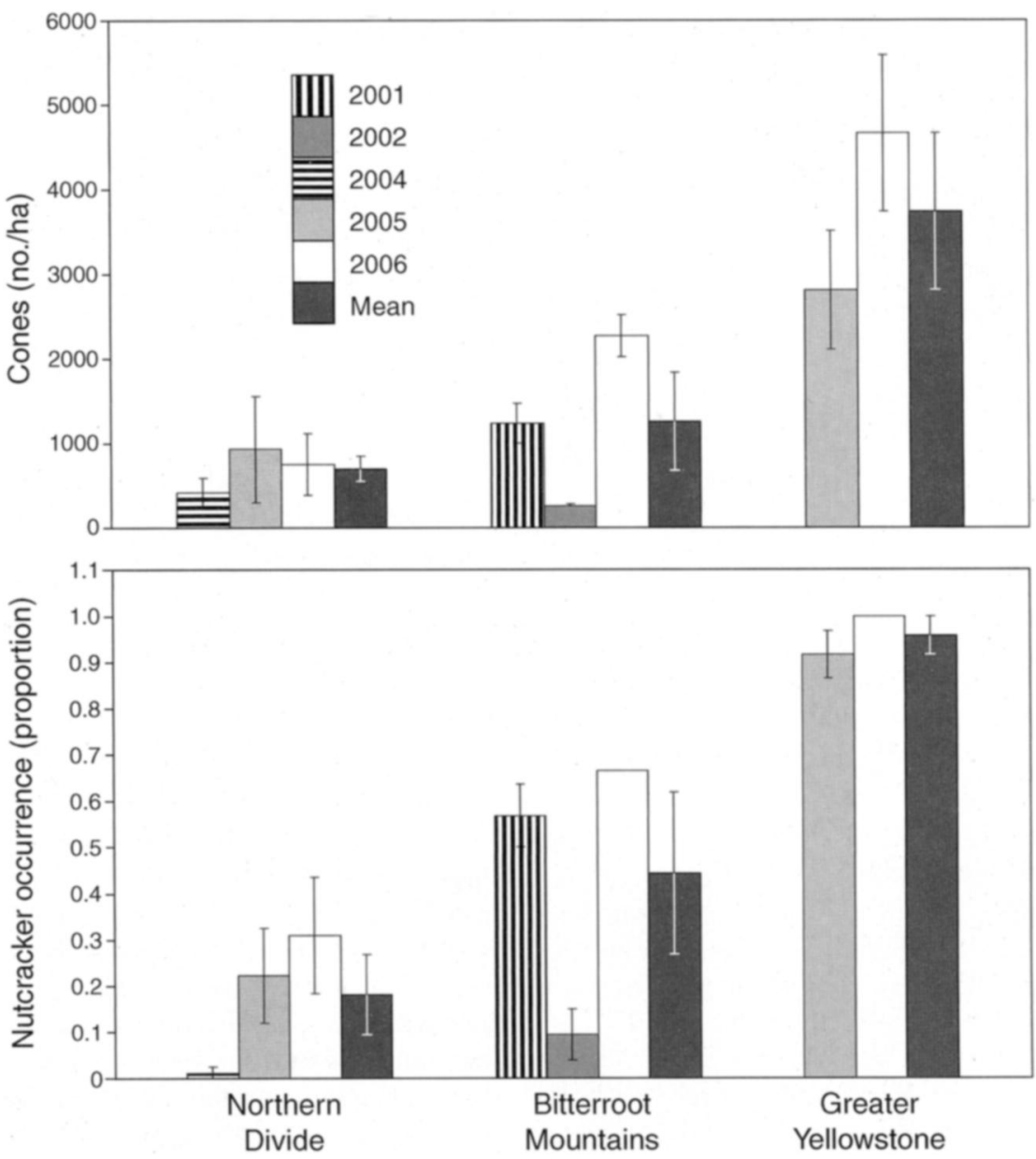

FIG. 4. Annual fluctuations of whitebark pine cone production and Clark's Nutcracker occurrence within and among three ecosystems in the Rocky Mountains, USA, derived from site-level estimates. Nutcracker occurrence is the proportion of total observation hours with $\geq 1$ bird observed. Data are means $\pm \mathrm{SE}$.

There was a significant ecosystem effect on the likelihood of whitebark pine seed dispersal by Clark's Nutcracker across all sites and years $\left(\chi^{2}=17.18, \mathrm{df}=2\right.$, $n=42$ site-years, $P<0.001)$. We failed to observe at least a single nutcracker (and thus a seed-dispersal event) during the period of seed dispersal (19 August to 6 September) in $80 \%$ of the Northern Divide site-years $(n=20)$, while $40 \%$ of site-years $(n=10)$ in the Bitterroot Mountains failed to have any birds during this critical time. In contrast, nutcrackers were present and dispersing seeds in all sites in all years in the Greater Yellowstone Ecosystem $(n=12)$.

An ecosystem-level comparison (all sites and years aggregated) showed that mean whitebark pine cone production (in number per hectare) and bird abundance (in number per hour) were lowest in the Northern Divide, which also corresponded to the lowest density of whitebark pine regeneration (seedlings $\leq 50 \mathrm{~cm} / \mathrm{ha}$; Table 3). The Northern Divide had $80 \%$ and $75 \%$ fewer seedlings than the Bitterroot Mountains and Greater Yellowstone, respectively. Mean whitebark pine cone production and bird abundance were highest in the Greater Yellowstone among the three ecosystems. The Bitterroot Mountains had slightly higher mean regeneration, but with much greater heterogeneity (in terms of percentage SE) compared to the Greater Yellowstone (Table 3).

\section{DisCUSSION}

Our results indicate that there is a threshold of whitebark pine cone production below which there is a rapid decline in the frequency of Clark's Nutcracker occurrence and probability of seed dispersal. When cone production declines from 700 to 300 cones per hectare (42.9 to $32.5 \ln [\text { cones/ha] }]^{2}$ ), the estimated frequency of nutcracker occurrence declines from 0.4 to 0.1 and probability of seed dispersal from 0.7 to 0.3 (Figs. 3 and 5). If the trends identified here continue, ecologically significant seed-dispersal services from Clark's Nutcrackers in the Northern Divide Ecosystem may well be lost, effectively disconnecting the dispersal mutualism between nutcrackers and whitebark pine. If tree and 


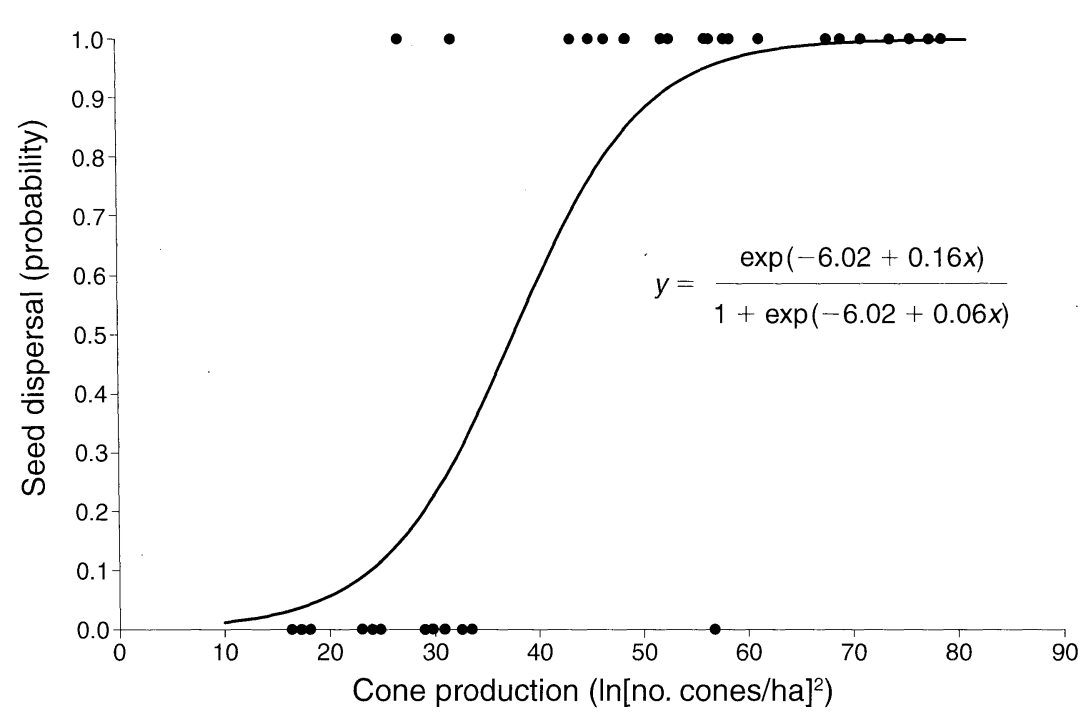

FIG. 5. Binary logistic regression analysis of Clark's Nutcracker seed dispersal $(1=$ dispersed, $0=$ not dispersed $)$ as a function of mean annual whitebark pine cone production in Rocky Mountain forest sites, USA $(n=34)$. The solid line represents the probability function derived from the prediction equation. A solid circle along the $y$-axis " 1 " line indicates that a site had a seeddispersal event recorded, and a circle along the " 0 " line indicates that none was recorded.

seedling mortality from white pine blister rust continue, coupled with tree loss from the native mountain pine beetle, Northern Divide populations will become smaller and more isolated, with increased risk of extinction due to stochastic perturbations (Shaffer 1981).

Clark's Nutcrackers showed sensitivity to available food energy at the site level across all research sites, with increasing frequency of occurrence as whitebark pine cone production increased. At the ecosystem level, the Greater Yellowstone may be considered heuristically as a natural control and used to compare the effects of whitebark pine forest health conditions on cone production, nutcracker occurrence, probability of seed dispersal, and environmental carrying capacity for the bird. Although the blister rust pathogen in the Greater Yellowstone may lead to significant future mortality, the percentage infection there was the lowest of the three ecosystems. Damage and mortality from blister rust in these Greater Yellowstone sites were apparently not yet high enough to reduce live basal area and cone production to the point of impacting nutcracker seed dispersal. However, it is also possible that other sites with lower mortality and damage from blister rust and mountain pine beetle could provide better controls for this study than the Greater Yellowstone sites, and demonstrate even higher occurrences of nutcrackers. Nevertheless, live whitebark pine basal area and cone production were highest for this study in the Greater Yellowstone; and, nutcrackers were present in $96 \%$ of the sampled hours; $100 \%$ of the research sites had seed dispersal; and the overall mean number of birds was 6.1 birds/ $h-20$ times greater than that in the Northern Divide. Infection and mortality were greater and basal area and cone production lower in the Bitterroot Mountains compared to the Greater Yellowstone; nutcracker incidences were also lower (present in $42 \%$ of sampled hours, $60 \%$ of research sites with dispersal, overall mean of $2.0 \mathrm{birds} / \mathrm{h}$ ). Whitebark pine forest decline was most severe in the Northern Divide, where rust infection and tree mortality levels were the highest and live basal area and cone production the lowest among the three ecosystems. Nutcrackers rarely visited Northern Divide sites during the three years of investigation, and then only in low numbers (present in $14 \%$ of hours sampled, $20 \%$ of research sites with dispersal, overall mean of 0.3 birds/h). As blister rust infection and tree mortality increase, live whitebark pine basal area and cone production decrease, thereby

TABLE 3. Ecosystem comparison of whitebark pine cone production, nutcracker abundance, and regeneration.

\begin{tabular}{|c|c|c|c|c|c|c|c|c|c|c|c|c|}
\hline \multirow{2}{*}{$\begin{array}{l}\text { Ecosystem, and } \\
\text { no. of sites }\end{array}$} & \multicolumn{4}{|c|}{ Cones (no./ha) } & \multicolumn{4}{|c|}{ Clark's Nutcracker (no./h) } & \multicolumn{4}{|c|}{ Seedlings $\leq 50 \mathrm{~cm}$ (no./ha) } \\
\hline & Mean & $\% \mathrm{SE}$ & Min. & Max. & Mean & $\% \mathrm{SE}$ & Min. & Max. & Mean & $\% \mathrm{SE}$ & Min. & Max. \\
\hline Northern Divide, 10 & 641.2 & 33.4 & 57.2 & 4068.5 & 0.3 & 33.3 & 0 & 10 & 70.2 & 30.2 & 0 & 343.2 \\
\hline Bitterroot Mountains, 6 & 1055.5 & 25.2 & 218.7 & 2516.8 & 2.0 & 15.0 & 0 & 33 & 360.5 & 65.8 & 0 & 2370.0 \\
\hline Greater Yellowstone, 8 & 3635.2 & 17.9 & 911.7 & 7126.9 & 6.1 & 13.1 & 0 & 25 & 281.5 & 28.6 & 0 & 928.7 \\
\hline
\end{tabular}

Note: $\% \mathrm{SE}=$ percentage standard error (i.e., $\mathrm{SE}$ of a sample mean divided by sample mean $\times 100$ ). 
diminishing nutcracker occurrence, and seed-dispersal incidence at the ecosystem level.

\section{Clark's Nutcracker energetics and white pine blister rust}

The ultimate factor relative to survival that influences an emigration response in nutcrackers is lack of seeds to cache, which translates to diminished survival through the subalpine winter, and decreased reproduction (e.g., Lack 1954). The proximate stimulus is less certain. Vander Wall and colleagues (1981) proposed that nutcrackers cue in on the absence of limber (Pinus flexilis) and piñon pine ( $P$. edulis and $P$. monophylla) cones, thereby triggering irruptions prior to actual food shortage. Blister rust infection reduces cone production in whitebark pine forests, directly constraining the factor determining whether nutcrackers settle and remain in a forest to disperse seeds. Whether this evolved survival response to food shortage will result in a prolonged absence of nutcrackers from high-mortality/low coneproducing areas is unknown. But if it does, a positive feedback scenario is likely for whitebark pine: decreasing regeneration with increasing tree mortality, and accelerated population decline.

Vander Wall and Balda (1977) estimated that a single adult nutcracker requires $4.95 \times 10^{4} \mathrm{KJ}$ of edible energy to survive a subalpine winter. Tomback (1982) calculated whitebark pine seed edible dry-mass energy to be 32.3 $\mathrm{KJ} / \mathrm{g}$ and mean seed mass $8.0 \times 10^{-2} \mathrm{~g}$. Given an average of 45 seeds per cone (Tomback 1978), we estimated that a single adult bird would require a minimum of 426 cones to cache the necessary 19150 seeds. Adult nutcrackers appear to cache from 1.8 to 5 times the minimum amount needed (Vander Wall and Balda 1977, Tomback 1982, Vander Wall 1988). Some of these caches may be consumed by rodents (e.g., Tomback 1980) and others fed to nestling and juvenile nutcrackers (Mewaldt 1956, Tomback 1978). Given this energy range (1.8-5 times minimum energy requirements); one adult would need to cache the seeds from 767-2130 cones. Our results provide an interesting comparison to these values. Three-year mean cone production in the Northern Divide Ecosystem was below the minimum level of this energy range $(641 \pm 214$ cones/ha [mean \pm SE]; $n=20$ sites) and nutcrackers were rare and in low numbers (Fig. 4 and Table 3). Twenty percent of Northern Divide sites did have at least one observation of a seed-dispersal event, and mean cone production in these dispersed sites was within the energy range (1421 \pm 719 cones/ha; $n=5$ sites). Moreover, mean cone production of all sites with seed dispersal-regardless of ecosystem - was above the maximum of the required energy range (2619 \pm 433 cones/ha; $n=23$ sites); conversely, mean production was below the minimum in all sites with no seed dispersal ( $356 \pm 95$ cones/ha; $n=19$ sites).

It is not clear how the available energy per hectare per bird might relate to assessments of sufficient food supply, since nutcrackers forage for the seeds of whitebark and other pines widely over the local landscape (e.g., Tomback 1978, 1982). The putative relationships to previous calculations of energy requirements could well be spurious, or could reflect real cues and cognitive assessment processes. However, our results are consistent with several independently derived estimates of nutcracker energy requirements, and do support the interpretation that the birds are able to assess cone crops and will be less frequent visitors and in lower numbers in forests with cone production below minimum levels.

\section{Management recommendations}

Based on previous estimates and the results from our study, we propose that a threshold of 1000 cones/ha averaged over a given site is needed for a high likelihood of nutcracker presence at the time of seed dispersal. For example, our models predict nutcracker occurrence frequency of 0.46 (Fig. 3) and seed-dispersal probability of 0.83 (Fig. 5) for a site with mean production of 1000 cones/ha. These estimates are not without error, and the local spatial extent over which this magnitude of cone production must occur needs more detailed investigation. They do, however, form a reasonably sound basis to begin to formulate whitebark pine management and restoration decisions.

If estimates of cone production are not readily obtainable for a given management area, live whitebark pine basal area can be used instead as a predictor of cone production. Mean cone production was significantly correlated with mean basal area over the 24 sites sampled $(r=0.808$ : Table 2). Graphical analysis of mean cone production plotted against basal area suggests that $5.0 \mathrm{~m}^{2} /$ ha defines the lower limit of mean live whitebark pine basal area needed to produce an average of 1000 cones/ha. Furthermore, research sites where nutcracker seed dispersal was never observed had a mean live whitebark pine basal area of $1.58 \pm 0.78$ $\mathrm{m}^{2} /$ ha (mean $\pm \mathrm{SE} ; n=7$ sites); sites with nutcracker seed dispersal observed in some years (and not in others) had a mean live basal area of $5.03 \pm 1.01 \mathrm{~m}^{2} / \mathrm{ha}(n=7$ sites); while sites with observations of nutcracker seed dispersal in all years had a mean basal area of $15.27 \pm$ $2.51 \mathrm{~m}^{2} /$ ha $(n=10$ sites $)$. Therefore, we estimate that whitebark pine forests with mean basal area $\approx 5.0 \mathrm{~m}^{2} / \mathrm{ha}$ will be able to produce $\approx 1000$ cones/ha, at least in some high-production years, and consequently attract and maintain nutcrackers through the critical period of seed dispersal. However, because blister rust was present in all three of our study ecosystems, and because there is substantial variability in cone production among sites, the proposed cutoff value should be interpreted cautiously and accompanied by a site-specific evaluation of conditions.

Although the mutualism between Clark's Nutcracker and whitebark pine is not currently threatened throughout their ranges of sympatry (Fig. 1), our results clearly show a trajectory of decreasing interaction between the 
bird and pine in the Northern Divide Ecosystem. Our results point to decreased nutcracker seed-dispersal services as the principal mechanism behind reduced regeneration in the Northern Divide (Table 3). It is apparent that active management will be needed to reverse this downward trend. Sites with $<5.0 \mathrm{~m}^{2} /$ ha of live whitebark pine and producing $<1000$ cones/ha will require planting of rust-resistant seedlings, especially with further whitebark pine losses highly likely. Given the high levels of rust infection and tree mortality, and the low levels of live basal area documented, it is likely that many whitebark pine forests in the Northern Divide are no longer sustainable without restoration planting. However, our data show that sites that exceed the 5.0 $\mathrm{m}^{2}$ /ha threshold can still rely on nutcracker seed dispersal in some years, although these forests will lose whitebark pine over time as blister rust infection kills trees and damages canopies and as mountain pine beetle outbreaks continue. Managers are encouraged to identify such sites and use appropriate silvicultural treatments to increase nutcracker-caching habitat, at least for the immediate future.

As an example, if a whitebark pine forest has $>5.0$ $\mathrm{m}^{2}$ /ha of live basal area, is at least 10 ha in area, and is not isolated from other whitebark forests, it could serve as a natural seed source for a restoration project. Removal (cutting) of competing shade-tolerant trees followed by prescribed burning at a location within 10 $\mathrm{km}$ of the whitebark pine seed source would likely attract nutcracker caching and increase the likelihood of natural regeneration (Keane and Arno 2001). Sitespecific knowledge of whitebark pine forest attributes would also allow fire managers to make informed decisions regarding "wildland fire use," which entails deciding when and where to allow lighting-ignited fires to burn. Wildland fires could be allowed to burn in subalpine forests where the probability of nutcracker seed dispersal is high and the potential for damage to humans and property is low. Finally, knowing which forests have whitebark pine basal area below $5.0 \mathrm{~m}^{2} /$ ha would allow managers to prioritize areas for planting with the limited number of rust-resistant seedlings available (e.g., Mahalovich et al. 2006).

Natural regeneration, facilitated by restoration treatments as described above, should include a higher proportion of rust-resistant individuals relative to the parent trees because of ongoing mortality and damage from blister rust in susceptible trees. In some remote locations the use of wildland fire may be the best approach to whitebark pine restoration, given reasonably healthy seed sources. However, seedlings that are susceptible to blister rust have a poor chance of survival in areas of high blister rust infection levels, and the need to plant rust-resistant seedlings may be inevitable. Planting rust-resistant seedlings may well be the best strategy for spreading genetic resistance to blister rust as rapidly as possible and ensuring that whitebark pine will remain on the landscape.

\section{Conclusions}

Here we have provided evidence of a threat to a North American bird-pine mutualism that is not caused by direct habitat destruction, overhunting, or isolation, but rather results from an exotic, invasive pathogen reducing the food rewards that drive an obligate mutualism. Our results demonstrate that easily measured site variables (cone production and live basal area) can be used to predict the degree to which a fundamental ecological interaction (bird-pine seed dispersal) has been altered by human-induced factors. Moreover, by quantifying interactions within three distinct ecosystems that varied in forest-health parameters, we were able to identify and estimate thresholds that are needed to maintain the mutualism. Knowledge of these thresholds should prove useful for informing management and focusing restoration activities, and serve as an example to other systems where a mutualism is threatened.

\section{ACKNOWLEDGMENTS}

We thank Ward McCaughey and Robert Keane from the USDA Forest Service Rocky Mountain Research Station, Kathy Tonnessen from the Rocky Mountain Cooperative Ecosystem Studies Unit, Tara Carolin from Glacier National Park, and Dan Reinhart from Yellowstone National Park for support and assistance throughout this project. Sean Sweeney, John Fothergill, Brian Cook, and Brett Stauffer provided excellent field assistance and helpful data entry. We are grateful to Hans Zuuring and Elizabeth Crone for analysis consultations, Lisa McKinney for creating Figs. 1 and 2, and Anna Sala, Hans Zuuring, and two anonymous reviewers for thoughtful manuscript reviews. Funding was provided by a USDI Cooperative Conservation Initiative grant (CA1200-99-007), USFS Research Joint Venture Agreements (01-JV-11222048-150 and 05-JV11221648-156), a USDA McIntire-Stennis Research Program grant, a National Park Service scholarship, and the College of Forestry and Conservation, University of Montana.

\section{Literature Cited}

Bock, C. E., and L. W. Lepthien. 1976. Synchronous eruptions of boreal seed-eating birds. The American Naturalist 110: 559-571.

Bond, W. J. 1994. Do mutualisms matter? Assessing the impact of pollinator and disperser disruption on plant extinction. Philosophical Transactions of the Royal Society of London B 344:83-90.

Christian, C. E. 2001. Consequences of a biological invasion reveal the importance of mutualism for plant communities. Nature 413:635-639.

Cordeiro, N. J., and H. F. Howe. 2001. Low recruitment of trees dispersed by animals in African forest fragments. Conservation Biology 15:1733-1741.

Cordeiro, N. J., and H. F. Howe. 2003. Forest fragmentation severs mutualism between seed dispersers and an endemic African tree. Proceedings of the National Academy of Sciences (USA) 100:14052-14056.

Davis, J., and L. Williams. 1957. Irruption of the Clark Nutcracker in California. Condor 59:297-307.

Davis, J., and L. Williams. 1964. The 1961 Irruption of the Clark's Nutcracker in California. Wilson Bulletin 76:10-18.

Hoff, R. J. 1992. How to recognize blister rust infection on whitebark pine. USDA Forest Service Research Note INTRN-406.

Hoff, R. J., S. K. Hagle, and R. G. Krebill. 1994. Genetic consequences and research challenges of blister rust in whitebark pine forests. Pages 118-126 in W. C. Schmidt 
and F. K. Holtmeier, editors. Proceedings of an International Workshop on Subalpine Stone Pines and Their Environment: the Status of Our Knowledge. General Technical Report INT-GTR-309. USDA Rocky Mountain Research Station, Ogden, Utah, USA.

Hutchins, H. E., and R. M. Lanner. 1982. The central role of Clark's Nutcracker in the dispersal and establishment of whitebark pine. Oecologia 55:192-201.

Insightful Corporation. 2005. S-Plus 7.0 for Windows. Insightful Corporation, Seattle, Washington, USA.

Janzen, D. H. 1971. Seed predation by animals. Annual Review of Ecology and Systematics 2:465-492.

Keane, R. E., and S. F. Arno. 2001. Restoration concepts and techniques. Pages $367-400$ in D. F. Tomback, S. F. Arno, and R. E. Keane, editors. Whitebark pine communities: ecology and restoration. Island Press, Washington, D.C., USA.

Keane, R. E., P. Morgan, and J. P. Manakis. 1994. Landscape assessment of the decline of whitebark pine (Pinus albicaulis) in the Bob Marshall Wilderness Complex, USA. Northwest Science 68:213-229.

Kendall, K. C., and R. E. Keane. 2001. Whitebark pine decline: infection, mortality, and population trends. Pages $221-242$ in D. F. Tomback, S. F. Arno, and R. E. Keane, editors. Whitebark pine communities: ecology and restoration. Island Press, Washington, D.C., USA.

Lack, D. 1954. The natural regulation of animal numbers. Oxford University Press, London, UK.

Little, E. L., Jr. 1971. Atlas of United States Trees. Volume 1. Conifers and important hardwoods. Miscellaneous Publication number 1146. USDA Forest Service, Washington, D.C., USA.

Logan, J. A., and J. A. Powell. 2001. Ghost forests, global warming, and the mountain pine beetle (Coleoptera: Scolytidae). American Entomologist 47:160-172.

Loiselle, B. A., and J. G. Blake. 2002. Potential consequences of extinction of frugivorous birds for shrubs of a tropical wet forest. Pages 397-406 in D. J. Levey, W. R. Silva, and M. Galetti, editors. Seed dispersal and frugivory: ecology, evolution, and conservation. CABI Publishing, Wallingford, UK.

Mahalovich, M. F., K. E. Burr., and D. L. Foushee. 2006. Whitebark pine germination, rust resistance, and cold hardiness among seed sources in the Inland Northwest: planting strategies for restoration. USDA Forest Service Proceedings RMRS-P-43.

McConkey, K. R., and D. R. Drake. 2002. Extinct pigeons and declining bat populations: Are large seeds still being dispersed in the tropical Pacific? Pages 381-395 in D. J. Levey, W. R. Silva, and M. Galetti, editors. Seed dispersal and frugivory: ecology, evolution, and conservation. CABI Publishing, Wallingford, UK.

McDonald, G. I., and R. J. Hoff. 2001. Blister rust: An introduced plague. Pages 193-220 in D. F. Tomback, S. F. Arno, and R. E. Keane, editors. Whitebark pine communities: ecology and restoration. Island Press, Washington, D.C., USA.
McKinney, S. T., and D. F. Tomback. 2007. The influence of white pine blister rust on seed dispersal in whitebark pine. Canadian Journal of Forest Research 37:1044-1057.

Meehan, H. J., K. R. McConkey, and D. R. Drake. 2002. Potential disruptions to seed dispersal mutualisms in Tonga, Western Polynesia. Journal of Biogeography 29:695-712.

Mewaldt, L. R. 1956. Nesting behavior of the Clark Nutcracker. Condor 58:3-23.

Microsoft Corporation. 2003. Microsoft Office Excel 2003. Microsoft Corporation, Redmond, Washington, USA

Paillet, F. L. 2002. Chestnut: history and ecology of a transformed species. Journal of Biogeography 29:1517-1530.

Rizzo, D. M., and M. Garbelotto. 2003. Sudden oak death: endangering California and Oregon forest ecosystems. Frontiers in Ecology and the Environment 1:197-204.

Schoettle, A. W. 2004. Developing proactive management options to sustain bristlecone and limber pine ecosystems in the presence of a non-native pathogen. Pages 146-155 in W. D. Shepperd and L. G. Eskew, compilers. Silviculture in special places: Proceeding of the National Silviculture Workshop. Proceedings RMRS-P-34. USDA Rocky Mountain Research Station, Fort Collins, Colorado, USA.

Schwandt, J. W. 2006. Whitebark pine in peril: a case for restoration. USDA Forest Service Report R1-06-28.

Shaffer, M. L. 1981. Minimum population sizes for species conservation. BioScience 31:131-134.

SPSS. 1999. SPSS 10.0 for Windows. SPSS, Chicago, Illinois, USA.

Tomback, D. F. 1978. Foraging strategies of Clark's nutcracker. Living Bird 16:123-161.

Tomback, D. F. 1980. How nutcrackers find their seed stores. Condor 82:10-19.

Tomback, D. F. 1982. Dispersal of whitebark pine seeds by Clark's nutcracker: a mutualism hypothesis. Journal of Animal Ecology 51:451-467.

Tomback, D. F. 1998. Clark's Nutcracker (Nucifraga columbiana). Number 331 in A. Poole and F. Gill, editors. The birds of North America. The Birds of North America, Philadelphia, Pennsylvania, USA.

Tomback, D. F., and K. A. Kramer. 1980. Limber pine seed harvest by Clark's Nutcracker in the Sierra Nevada: timing and foraging behavior. Condor 82:467-468.

Tomback, D. F., and Y. B. Linhart. 1990. The evolution of bird-dispersed pines. Evolutionary Ecology 4:185-219.

Travest, A., and N. Riera. 2005. Disruption of a plant-lizard seed dispersal system and its ecological effects on a threatened endemic plant in the Balearic Islands. Conservation Biology 19:421-431.

Vander Wall, S. B. 1988. Foraging of Clark's Nutcrackers on rapidly changing pine seed resources. The Condor 90:621631.

Vander Wall, S. B., and R. P. Balda. 1977. Coadaptations of the Clark's Nutcracker and the piñon pine for efficient seed harvest and dispersal. Ecological Monographs 74:89-111.

Vander Wall, S. B., S. W. Hoffman, and W. K. Potts. 1981. Emigration behavior of Clark's Nutcracker. Condor 83:162170 .

\section{APPENDIX}

Table of results from an independent data set used to test logistic-regression model predictions of Clark's Nutcracker seed dispersal of whitebark pine (Ecological Archives A019-025-A1). 